\section{River Bank Protection}

For the Inland Navigation Section of the Sixteenth International Congress of Navigation, Brussels, 1935, Dr. Brysson Cunningham prepared a report on "The Estuarial Embankments of the River Thames". Of the origins of these walls little is definitely known and, in his "History of the Port of London", Sir Joseph Broodbank inclines to the view that their construction was a gradual and piecemeal process undertaken locally with the purpose of reclaiming for agriculture the valuable lands along the banks of the river, and probably initiated by immigrants from Flanders familiar with work of this kind. As he also says, "The builders in carrying out their object would not trouble themselves as to the effect their work had on the stream nor did they realise that they were, in fact, performing a mighty service in providing for London one of its greatest assets as a Port". Records of repairs and alterations have been traced back to the time of Edward II, and about that time Commissions of Sewers-using the word in its original sense--began to be appointed to exercise jurisdiction in several localities. Until 1930, when the Land Drainage Act established Catchment and Drainage Boards to take over their duties, these Commissions acted under the authority of an Act of 1531 to protect the lands from being flooded either by inundation or accumulation of superfluous waters. As consultant engineer to two of these bodies entrusted with portions of the Thames Embankments, Dr. Brysson Cunningham was able to advise the Congress as to the nature of the problems presented, and gave an account of the construction, maintenance, repair and renewal of these walls. Altogether, the earthworks on both sides of the river below London Bridge have a total length of approximately 120 miles and give protection to 64 square miles of low-lying marshland. Being 4-5 feet above Ordnance Datum while H.W.O.S.T. level is 10-13 feet, these extensive lands would, without protection, become permanently flooded. In the report, the several inimical agencies are described and, by maps, sections and diagrams, the methods and materials used to ensure adequate defence are fully exhibited.

\section{Research on Combustion}

No one is better qualified than Prof. W. A. Bone to give an account of "Fifty Years of Combustion Research" - the title of his William Young Memorial Lecture, delivered to the North British Association of Gas Managers on September 12. The account gives a readable and comprehensive story mainly of the work due to the late Prof. H. B. Dixon and his school, and not least of Prof. Bone himself and his pupils. The lecture included some of the more recent observations on the combustion of gases at very high initial pressures, with activation of nitrogen, the description of some of the curious phenomena such as the 'spin' of the flame head in the detonation wave-observations calling for remarkable achievements in highspeed photography. The existence recently observed of double ranges of ignition temperatures of gases with an intervening 'inert' zone of temperature emphasises the complexity of the process of ignition. The 'chain theory' which has been so extensively used to account for combustion phenomena is held to be not 'mere moonshine' but to merit critical reception when capable of being harmonised with experiment. Prof. Bone closes with the insistence on the necessity of perpetual experimentation, for as Priestley said, "Speculations without experiments have always been the bane of natural philosophy".

\section{Chemical and Physical Society, University College}

THE Chemical and Physical Society, now the senior Society of University College, London, opened its sixtieth session on October 15. Before a large and distinguished gathering Dr. Henry Forster Morley, a founder-member and third president of the Society, unveiled oak panels bearing the names of the former presidents, many of whom were actually present. It was unfortunate that Sir Oliver Lodge, who was president of the Society in its first two years, was unavoidably absent on this occasion. The unveiling itself, in accordance with the principles of the Society, was performed electrically by means of an engraved silver switch, which was afterwards formally presented to Dr. Forster Morley. Mr. C. F. Goodeve, this year's president, who was in the chair, then introduced the other speakers, among whom were the Provost, who accepted the panels on behalf of the College, and Prof. A. W. Porter and Prof. M. W. Travers, who made a few interesting remarks about the earlier presidents. The secretary, Mr. R. H. Leach, thanked the many friends of the Society for their assistance, financial and otherwise.

\section{Preservation of Cliff Scenery}

Is a paper to Section E (Geography) of the British Association at Norwich on September 5, Dr. Vaughan Cornish directed attention to the menace afforded by private enclosure to the best of the cliff scenery of England and Wales. Of the 1,800 miles of coast line, about five hundred are cliff land, of which more than three hundred miles are in Devon, Somerset and Cornwall. For the most part, the cliff edge is still accessible to the pedestrian, but too often the landward side has been enclosed and thus the full enjoyment of the view is impaired. Dr. Cornish calculates that 40,000 houses would line the whole of the five hundred miles, and believes that with the present rate and spread of building it will not be many years before much of the cliffs will be enclosed. $\mathrm{He}$ advocates the public acquisition under the Town and Country Planning Act, supplemented if possible by other funds, of a strip of land 110 yards wide along all the cliffs. This would amount in all to 20,000 acres and the purchase figure would be approximately $£ 2,000,000$. Thus, for a relatively small cost the finest scenic treasures of the country would be preserved.

\section{Fossil Human Occipital Bone from Thames Gravels}

DuRING the recent meeting of the British Association at Norwich, Mr. Alvan T. Marston exhibited to Section H (Anthropology) a complete human 
occipital bone which he had found in the middle gravels of the 100-ft. terrace of the Thames at Swanscombe, Kent. The bone was associated with Acheulean flint implements, and is mineralised in the same way as the bones of the Pleistocene mammals occurring with it. The fossil was submitted to the Geological Survey, and Mr. Henry Dewey confirmed the determination of its geological age. Mr. Marston now writes that he has made an endocranial cast of the specimen and has consulted Sir Grafton Elliot-Smith, who expresses the opinion that "the exceptional size and form of the visual territories upon the two hemispheres of the endocranial cast, even if they suggest left-handedness, are definitely Simian and point to a much more primitive stage than Eoanthropus". The bone differs considerably from the occipital of Eoanthropus, and further discoveries to reveal the characters of the skull to which it belongs will be eagerly awaited.

\section{Ancient Ruins in East Africa}

AN archæological reconnaissance with the view of further investigation has been made recently by $\mathrm{Dr}$. L. S. B. Leakey on two sites in East Africa. Of these, one, the ruins of Gedi, an ancient city of considerable extent, sixty-five miles north of Mombasa, is already scheduled under the Ancient Monuments Preservation Ordinance; the other is the large assemblage of stone-built dwelling-places and tombs at Engaruka in the Great Rift Valley in Tanganyika, to which attention was directed as a new discovery in June last of Mr. T. E. Wetherell. The ruins at Gedi, though situated at no more than fifty yards from the Mombasa-Malindi road at their nearest point, are so obscured by a tangle of tropical vegetation as almost to escape notice. Trees of considerable size growing on or in the ruined structures afford some gauge of the antiquity of the ruins. According to Dr. Leakey's report (The Times, October 11) future investigation will reap a rich harvest. Town walls, buildings and tombs alike afford evidence of at least two, and possibly three, distinct periods of construction. The materials used consist of dressed blocks of coral, built up with a hard mortar and plastered to a smooth surface. In places, where the dressing is unplastered, as on the arches over doors and windows, it is extremely fine. It is Dr. Leakey's opinion that the ruins may be those of an Arab or Persian settlement of considerable antiquity, the first settlement possibly dating so far back as the beginning of the Christian era.

Dr. LEakey's investigations at Engaruka confirm previous reports of the extent of the site, though the limits at present are unknown. He estimates that the buildings in the North and South Ruins on the slope number five to seven thousand; and there are further structures in addition to the tomb mounds below in what he terms the Valley Ruins. The ruins are not entirely a new discovery, as recently reported. They had been visited by Dr. Hans Reck on his way to Oldoway in 1913, when he excavated one or two mounds ; and more recently a little digging has been done by British administrative officials. Dr. Leakey carried out one or two exploratory excavations of mounds and buildings, but failed to obtain any material, either skeletal or cultural, which throws light on the dating of the site. It is evidently not of high antiquity. The buildings are entirely of dry stone-walling, without mortar, and show no real skill in stone building. Inquiry among the Masai elicited the tradition that the ruins had been abandoned about one hundred years ago when the Masai drove out the ancestors of the present-day Warmbulu. A further tradition of a Portuguese leader or king at Engaruka may, it is thought, afford an explanation of how a people who do not now build in stone, nor live in towns or even villages, came to erect these stone structures in such numbers.

\section{Linguistic Research in Kashmir}

IT is reported that Colonel D. L. R. Lorimer, whose studies in Indo-Iranian linguistics are well known, accompanied by Mrs. Lorimer, has recently returned to Srinagar from an expedition of linguistic research among the mountain tribes of Hunza and the area to the north, upon which he has been engaged during the last fifteen months. The chief object of the expedition was to extend and complete Colonel Lorimer's studies of Burushaski, the language of the Burusho of Hunza ; but he has also devoted attention to Wakki, a language of the Iranian group spoken in Wakkan and also by Wakkan settlers in northern Hunza. Colonel Lorimer, it is stated in a dispatch from Srinagar in The Times of October 9, has succeeded in obtaining a record of a language, Boma, hitherto unknown, spoken by a tribe of musicians and metal workers who have been settled in Hunza for many generations. According to their own tradition, they are a people of Badakhshari origin, who at some period were transferred to the rule of the Mir of Hunza for services he had rendered the ruler of Badakhshan. They have remained an exclusive group and still do not intermarry with the Burusho, although they, like the other peoples of Hunza, are Moslems. Hence while they speak Burushaski fluently, they have retained their cultural and linguistic individuality intact. Their language, which is said not to resemble the Badakhshani of their traditional place of origin, appears to be more closely related to the Sanskritic than to the Iranian members of the Indo-Iranian linguistic group. If this be confirmed by further study, it would agree with the character of other languages of the so-called Dards of Hunza. Colonel Lorimer is now about to return to England for the purpose of studying the large amount of ethnographical and linguistic material he has collected among the less well-known mountain peoples of the area.

\section{Marine Research at Millport}

THE report for $1933-34$ of the Scottish Marine Biological Association, Millport, shows that much work has been done during the year. The director, Mr. R. Elmhirst, has studied specially the conditions under which shore algæ live, and subdivides the 